\title{
REPRESENTATION OF THE FACE OF THE CITY OF SERANG IN THE PRINT ADVERTISING OF 2018 MAYOR'S MEMORIES
}

\author{
Sigit Surahman, M. Arif Munawar, dan Meliana Pratiwi \\ saleseven@gmail.com \\ Program Studi Ilmu Komunikas/Jurnalistik, Universitas Serang Raya
}

\begin{abstract}
Print ads are currently getting shifted by technological developments, its role is still able to become one of the alternative media promo for prospective candidates of Mayor and Vice Mayor in Serang City for the period 2018-2023. This is seen so many posters, banners and even billboards in almost every corner of Serang City which is used by prospective couples. The existence of conventional media becomes an interesting phenomenon to be studied and semiotics study on print advertising media. This research uses qualitative research methods that are descriptive interpretive. By using the theory of representation from Stuart Hall, this study wanted to see how the prospective candidates represent the face of Serang City through print advertising media displayed by prospective couples. Based on the results of semiotic analysis of the face of Serang City 2018 print ads would prospective Serang Mayor 2018, looks every balloon has a characteristic of the design that he made to invite people choose himself. Creative packaging through the poster design of the balloons is seen not only on the tagline, but the clothes worn and not far from the norms that have been agreed by the people of Serang city that is religious, friendly and full of local wisdom.
\end{abstract}

Keyword: Print Ads, Visual Communication, Representation, Serang City 


\section{PENDAHULUAN}

Kota Serang adalah wilayah baru hasil pemekaran kabupaten Serang Provinsi Banten. Sebagai Ibu Kota Provinsi kehadirannya adalah sebuah konsekuensi logis dari keberadaan Provinsi Banten. Sejak abad ke-16, Serang merupakan pusat pemerintahan, pusat perdagangan dan pusat kebudayaan. Letak Kota Serang yang strategis menjadikannya sebagai jalur utama penghubung lintas Jawa-Sumatera. Pembentukan Kota Serang sendiri tak lepas dari amanat undang-undang nomor 23 tahun 2000 tentang pembentukan Provinsi Banten. Kota Serang lahir pada tanggal 10 Agustus 2007.

Kota Serang memiliki luas Wilayah 266,77 Km2 dengan jumlah penduduk sekitar 523.384 Jiwa. Batas wilayah Kota Serang sebelah utara yaitu Teluk Banten, Sebelah Timur Kecamatan Pontang, Kecamatan Ciruas, dan Kecamatan Keragilan Kabupaten Serang, Sebelah Selatan berbatasan dengan Kecamatan Cikeusal, Kecamatan Petir dan Kecamatan Baros Kabupaten Serang. Serta sebelah Barat berbatasan dengan Kecamatan Pabuaran, Kecamatan Waringin kurung dan Kecamatan Keramatwatu Kabupaten Serang. Dari 6 (enam) Kecamatan tersebut terdiri dari 20 kelurahan dan 46 Desa.

Sebagai ibukota provinsi paling barat di pulau jawa, Kota Serang memiliki wajah atau citra tersendiri yang menjadi ciri khas Kota Serang. Nilai budaya dan agama masih sangat kental di pegang teguh oleh penduduknya. Hal tersebut sesuai dengan slogan Kota Serang sebagai kota Madani. Slogan ini menegaskan tujuan pemerintah dengan prinsip :

1. Menghormati kebebasan beragama;

2. Menjaga persaudaraan antar umat beragama ;

3. Menjaga perdamaian dan kedamaian;

4. Menjaga persatuan;

5. Etika politik yang bebas bertanggung jawab;

6. Pemerintah yang melindungi hak dan kewajiban warga negara

Kota Serang, Banten, ternyata menduduki skor tertinggi sebagai kota paling aman di Indonesia. Tiga kota yang mengekor setelah Serang adalah Bengkulu, Yogyakarta, dan Bandung. Hal ini berdasarkan penelitian Indeks Kota Islami (IKI) yang dilakukan Maarif Institute seperti dikutip dari Kompas. Dari hasil penelitian ini, Serang memiliki nilai 82,5 sebagai kota paling aman. Variabel aman memiliki indikator, kebebasan beragama dan 
keyakinan, perlindungan hukum, kepemimpinan, pemenuhan hak politik perempuan, hak anak dan difabel.

Iklan cetak berupa poster merupakan karya seni atau desain grafis yang memuat komposisi gambar dan huruf di atas kertas berukuran besar (biasanya A3 atau lebih besar lagi). Pengaplikasiannya dengan ditempel di dinding atau permukaan datar lainnya dengan sifat mencari perhatian mata sekuat mungkin. Penggunaan desain dalam poster sangat berpengaruh pada bagaimana pesan itu tersampaikan. Salah satu komponen utama dalam poster kampanye politik yaitu foto. Sebuah foto dapat memberikan pesan politik yang efektif untuk membentuk citra seseorang. Sebuah foto mampu memberikan kenyataan dalam bentuk visual yang berperan besar mempengaruhi opini warga. Sebuah branding kampanye politik dengan menggunakan media poster atau media lainnya dapat berfungsi sebagai pengikat pesan yang disampaikan calon Walikota kepada masyarakat. Selain itu dalam poster terdapat simbol-simbol bagaimana wajah kota serang di representasikan. Berdasarkan latar belakang tersebut, peneliti tertarik melakukan penelitian dengan judul "Representasi Wajah Kota Serang dalam Iklan Cetak Para Bakal Calon Walikota Serang 2018” (Analisis Semiotika tentang Representasi Wajah Kota Serang dalam Iklan Cetak Bakal Calon Walikota Serang).

\section{TINJAUAN TEORITIS}

\section{Komunikasi Visual}

Komunikasi visual atau bisa juga bahasa visual merupakan studi aplikasi atas semantik yang merupakan turunan dari akar-akar filosofis yang sama halnya linguistik. Namun bahasa atau kode lisan atau tulisan yang menggunakan bahasa visual membentuk komunikasi yang dikembangkan dalam semantik produk dan simbol visual yaitu; garis warna, tekstur, rupa, dan bentuk yang bisa ditampilkan melalui foto, video, poster, baliho dan sebagainya. (Vihma 2009, 15-16).

Sebuah iklan terlihat sangat menyentuh dan dapat mempengaruhi orang yang melihatnya. Hal tersebut sangat dipengaruhi oleh salah satunya penggunaan tanda yang ditampilkan dalam iklan tersebut. Tanda merupakan suatu media untuk mengemas maksud atau pesan dalam setiap peristiwa komunikasi. Tanda mempunyai dua dimensi, yaitu ekspresi dan isi. Ekspresi merupakan bentuk fisik tanda atau tanda itu sendiri (Girsang dan Hapsari, 2015:145-146). 
Volume 5 Nomor 1, April 2019

\section{Teori Representasi}

Representasi secara singkat adalah salah satu cara untuk memproduksi makna. Representasi bekerja melalui sistem representasi yang terdiri dari dua komponen penting, yakni konsep dalam pikiran dan bahasa. Kedua komponen ini saling berkorelasi. Konsep dari sesuatu hal yang dimiliki dan ada dalam pikiran, membuat manusia atau seseorang mengetahui makna dari sesuatu hal tersebut. Namun, makna tidak akan dapat dikomunikasikan tanpa bahasa, sebagai contoh sederhana, konsep 'gelas' dan mengetahui maknanya. Maka seseorang tidak akan dapat mengomunikasikan makna dari 'gelas' (benda yang digunakan orang untuk tempat minum) jika seseorang tidak dapat mengungkapkannya dalam bahasa yang dapat dimengerti oleh orang lain (Surahman, 2014:44).

Giles (1999:56-57) dalam buku Studying Culture: A Practical Introduction, terdapat tiga definisi dari kata "represent"" yakni: To stand in for, To speak or act on behalf of, To re-present. Dalam praktiknya, ketiga makna dari representasi ini bisa menjadi saling tumpang tindih. Teori yang dikemukakan oleh Stuart Hall sangat membantu dalam memahami lebih lanjut mengenai apa makna dari representasi dan bagaimana caranya beroperasi dalam masyarakat budaya. Hall dalam bukunya Representation: Cultural Representation and Signifyig Practices "Representation connects meaning and language to culture.... Representation is an essential part of the process by which meaning is produced and exchanged between members of culture.

\section{Semiotika Charles Sanders Pierce}

Pierce adalah seorang filsuf Amerika yang memiliki pemikiran argumentatif, orisinil dan multidimensional. Ia tidak sekedar menerjemahkan istilah "semiotika" yang kini jadi populer itu, dari bahasa Yunani Kuno, tetapi ia juga menjadi seorang pemikir tentang karya-karya Kant dan Hegel yang ia baca dalam bahasa Jerman. Pierce terkenal karena teori tandanya. Di dalam lingkup semiotika, Pierce, sebagaimana dipaparkan Lechte (Lechte,2001;Sobur,2006:227) yang dikutip oleh Sobur, seringkali mengulang-ngulang bahwa secara umum tanda adalah yang mewakili sesuatu bagi seseorang. Semiotika berangkat dari tiga elemen utama, yang disebut Pierce teori segitiga makna atau triangle meaning. 
Gambar Segitiga Semiotik C.S. Pierce

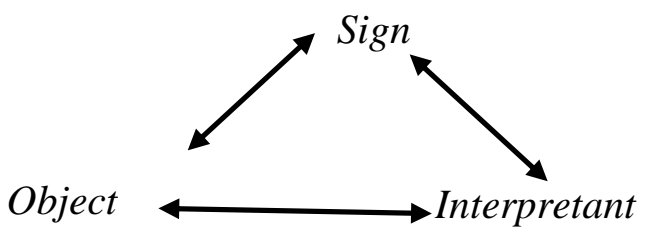

Sign atau tanda merupakan sesuatu yang berbentuk fisik yang dapat ditangkap oleh panca indera manusia dan merupakan sesuatu yang merujuk dan merepresentasikan hal lain diluar tanda itu sendiri. Berdasarkan objeknya, Pierce membagi tanda atas icon (ikon), index (indeks), dan symbol (simbol) (Sobur, 2006:41-42).

Ketiga jenis tanda hadir sekaligus dalam suatu waktu. Artinya, suatu representamen mengandung elemen ikon, indeks, dan simbol sekaligus. Suatu pakaian dapat menunjukkan ikon. Indeks hadir dalam bentuk latar belakang yang digunakan. Sementara simbol ditunjukkan seperti dalam gambar atau tulisan pada atau yang menyertai pakaian, yang dapat berdiri sendiri jika tanpa pakaian tersebut hadir (Ulfa,2016:404).

\section{METODE PENELITIAN}

Dalam penelitian ini, peneliti menggunakan paradigma interpretif. Menurut Morgan (1979) paradigma interpretif adalah paradigma yang menggunakan cara pandang para nominalis dari paham nominalisme yang melihat realitas sosial sebagai suatu yang tidak lain adalah label, nama, konsep yang digunakan untuk membangun realitas.

Metode penelitian yang digunakan adalah metode penelitian kualitatif. Riset kualitatif adalah riset yang data-datanya berupa statement-statement atau pernyataan-pernyataan dan berawal dari pendekatan interpretif (subyektif) (Kriyantono, 2006:52).

Objek kajian dalam penelitian ini adalah iklan cetak para bakal calon Walikota Serang yang disampaikan melalui media luar ruang, seperti poster atau pamflet. Iklan cetak para bakal calon Walikota Serang ini tertuang dalam bentuk visual berupa gambar, warna, serta jargon-jargon dari masing-masing kandidat. Penggunaan poster atau pamflet yang ditempatkan di tempat umum sepanjang jalan membuka peluang bagi para kandidat untuk memperkenalkan diri dan mempersuasi masyarakat tentang pesan yang ingin disampaikan para bakal calon Walikota Serang. 


\section{HASIL DAN PEMBAHASAN}

\section{Interpretasi Makna berdasarkan Identifikasi Jenis Tanda dalam Iklan Cetak}

\section{H. Subadri Usuluddin Bakal Calon Walikota Serang 2018}

Berdasarkan identifikasi tanda dalam iklan cetak bakal calon Walikota Serang 2018 yang dilakukan dengan mengadaptasi jenis-jenis tanda yang dikemukakan oleh Pierce, maka didapatkan tanda-tanda yang berupa ikon, indeks, dan simbol. Setelah proses identifikasi, peneliti melakukan interpretasi terhadap makna yang terkandung dalam tandatanda tersebut.

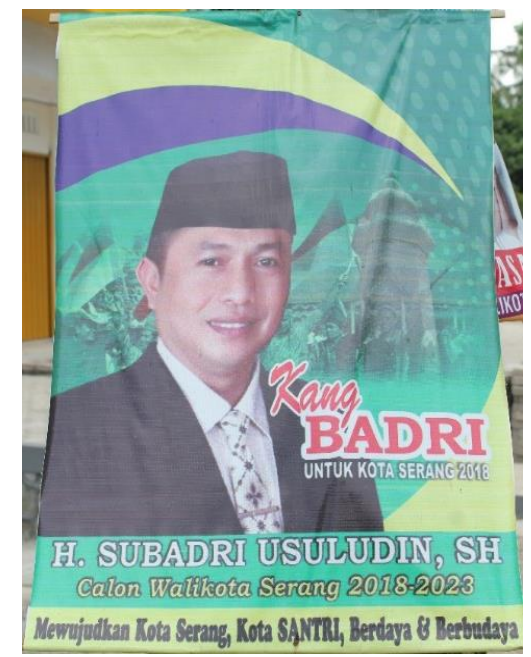

Gambar 1. H. Subadri Usuludin, SH

\begin{tabular}{|c|c|c|}
\hline Tanda & Penjelasan & Identifikasi \\
\hline Ikon & $\begin{array}{l}\text { Tanda berhubungan dengan } \\
\text { objek karena adanya } \\
\text { kesamaan, contohnya peta } \\
\text { atau foto. }\end{array}$ & $\begin{array}{l}\text { - } \text { Gambar Subadri } \\
\text { - } \text { Gambar Menara Banten } \\
\text { membar sekerumunan orang yang } \\
\text { yang diantaranya menggunakan baju daerah } \\
\text { yang berbeda-beda. } \\
\text { - } \text { Background hijau } \\
\text { - } \text { Gambar corak polkadot di ujung kanan atas } \\
\text { ujung runcing warna biru tua dan Kuning } \\
\text { muda. }\end{array}$ \\
\hline Indeks & $\begin{array}{l}\text { Adanya kedekatan eksistensi } \\
\text { antara tanda dengan objek } \\
\text { atau adanya hubungan sebab } \\
\text { akibat. }\end{array}$ & $\begin{array}{l}\text { - } \text { Pakaian Subadri } \\
\text { - Peci / Kopiah } \\
\text { - Tipografi }\end{array}$ \\
\hline Simbol & $\begin{array}{l}\text { Hubungan ini bersifat } \\
\text { konvensional dalam artian } \\
\text { ada persetujuan tertentu }\end{array}$ & $\begin{array}{l}\text { - Sub - Headline : Kang Badri untuk Kota } \\
\text { Serang } 2018\end{array}$ \\
\hline
\end{tabular}


antara para pemakai tanda.
- Headline : H. Subadri Usuludin, $\mathrm{SH}$

Calon Walikota Serang 2018-2023

- Tagline : Mewujudkan Kota Serang, Kota Santri, Berdaya \& Berbudaya

\section{Interpretasi Makna berdasarkan Identifikasi Jenis Tanda Ikon}

Berdasarkan hasil identifikasi tanda yang dilakukan terhadap iklan bakal calon Walikota Serang H. Subadri, maka didapatkan enam tanda jenis ikon. Pada tanda jenis ikon pertama, terdapat visual foto H. Subadri Usuluddin. Berdasarkan hubungan tanda dengan objek pada tipe ikon maka hubungan tanda dan objek dalam gambar ini sama yaitu gambar H. Subadri Usuluddin. Disini Interpretant-nya mengacu pada sosok H. Subadri Usuluddin sebagai bakal calon yang merupakan mantan ketua DPRD Kota Serang yang terlihat berpenampilan agamis, rapi, resmi dan berwibawa.

Gaya berpakaiannya menunjukan status sosialnya sebagai pejabat publik. Sosok H. Subadri Usuluddin yang pernah menjabat sebagai ketua DPRD Kota Serang memiliki peran penting terhadap Kota Serang sebelumnya. Beliau adalah orang nomor satu yang mewakili suara rakyat dan merelakan jabatannya untuk maju sebagai Walikota Serang. Terlihat adanya semangat tujuan dan amanah untuk membuat kota Serang menjadi lebih baik lagi melalui pengorbanannya melepas jabatan sebagai ketua DPRD. Sosoknya yang religius, amanah dan berwibawa merepresentasikan wajah Kota Serang sebagai kota yang teratur, kota yang kental sekali akan budaya islam dan kota yang masih menjunjung tinggi moral etika didalam masyarakat.

Pada tanda ikon yang kedua, terdapat gambar menara Banten. Disini interpretant nya mengacu pada Menara Banten yang menggambarkan simbol atau lambang dari peradaban Islam di Banten. Terkait dengan hal tersebut, maka menara Banten dapat merepresentasikan kentalnya peradaban Islam dari masa kerajaan hingga sekarang di Banten. Khususnya di Kota Serang yang secara geografis tidak jauh dengan tempat menara Banten berada. Kota Serang merupakan kota yang masih menjaga dan melestarikan keutuhan agama Islam sebagaimana sejarah peradabannya.

Tanda ikon ketiga yaitu gambar sekerumunan orang (laki-laki) yang memegang tongkat bendera merah putih yang diantaranya mengenakan pakaian berbeda-beda seperti baju daerah. Interpretantnya mengacu pada penampilan dan kegiatan yang dilakukan oleh sekerumunan orang tersebut seperti mengenakan pakaian daerah berbeda-beda dan 
memegang tongkat bendera merah putih. Sekerumunan orang yang terdiri dari laki-laki tersebut menggambarkan sebuah kekuatan dan demokrasi. Kerumunan orang tersebut mengenakan pakaian daerah yang berbeda-beda yang menggambarkan bhineka tunggal ika di Kota Serang. Sebab Kota Serang merupakan kota yang memiliki banyak penduduk dari luar daerah. Hal tersebut membuat keberagaman didalam budaya masyarakat. Walaupun begitu penduduk Kota Serang tetap hidup rukun dan damai. Adapun kegiatan yang dilakukan dengan memegang tongkat bendera merah puth menggambarkan negara Indonesia.

Maka apabila dikaitkan dari ikon diatas dapat merepresentasikan wajah Kota Serang yang memiliki budaya Bhinneka Tunggal Ika yang tinggi dan tetap rukun berdampingan dan saling menghargai, menjunjung tinggi demokrasi. Karena walaupun Kota Serang memiliki banyak etnis yang berbeda tapi mereka tetap satu Indonesia.

Pada tanda ikon keempat yaitu latar belakang yang berwarna hijau. Interpretantnya mengacu pada warna hijau yang dipakai sebagai warna dasar pada iklan bakal calon walikota H. Subadri. Warna hijau menggambarkan keseimbangan, kesejukan, dan kedamaian. Warna hijau seringkali dipakai sebagai warna yang berhubungan dengan urusan agama Islam. Seperti bendera negara Arab Saudi, gambar poster menyambut bulan Ramadhan, Idul Fitri dan lain-lain.

Hal tersebut dikarenakan warnah hijau memiliki makna yang sesuai dengan ajaran agama Islam. Agama Islam merupakan agama yang menyejukan hati dan menentramkan jiwa. Maka, warna hijau merepresentasikan wajah Kota Serang sebagai kota yang damai dan tentram. Bisa pula merepresentasikan sebuah identitas agama mayoritas yang dianut oleh masyarakat Kota Serang yaitu agama Islam.

Tanda ikon yang kelima yaitu motif polkadot yang hanya berada di ujung kanan atas. Interpretantnya adalah sama yaitu motif polkadot. Warnanya terlihat samar sehingga tidak terlalu mencolok pada iklan cetak bakal calon walikota H. Subadri. Menurut Kamus Besar Bahasa Indonesia kata polkadot memiliki arti corak pada kain berbentuk bulatan (berbagai ukuran) dengan jarak yang sama, biasanya di atas dasar yang polos. Dalam hal ini corak polkadot diaplikasikan pada media kertas. Motif polkadot menggambarkan kepercayaan sebagai pembawa kebahagiaan dan kemakmuran karena bentuknya yang bulat tanpa memiliki ujung dan dengan jumlahnya yang banyak dan teratur. Terakhir, tanda ikon yang keenam yaitu ornamen dua garis perspektif melengkung berwarna kuning muda (atas) 
dan biru tua (bawah). Interpretantnya mengacu pada bentuk perspektif garis lengkung serta warna yang dipakai yaitu kuning muda dan biru tua. Garis lengkung memiliki kesan luwes dan lemah lembut. Garis lengkung menggambarkan karakter ringan, dan dinamis.Adapun perspektif ujung garis yang runcing memberikan kesan tegas. Dalam hal ini garis lengkung tersebut memiliki volume sehingga membuatnya terlihat tebal. Ketebalan garis tersebut di isi dengan warna kuning muda dan biru tua. Keduanya menempel berdampingan.

Warna kuning muda yang terdapat pada bagian atas menggambarkan rasa optimis, energik, bijaksana, cerdas, dan kreatif. Namun warna kuning yang terlihat muda atau pucat memberikan kesan dalam jumlah seberapa besar dan seberapa kuat makna yang digambarkan tersebut. Sedangkan warna biru tua menggambarkan profesionalitas dan jati diri yang tangguh. Maka apabila dikaitkan dari ikon diatas dapat merepresentasikan wajah Kota Serang yang dinamis dan memiliki rakyat yang berjati diri yang tangguh.

\section{Interpretasi Makna berdasarkan Identifikasi Jenis Tanda Indeks}

Pada tanda tipe indeks maka hubungan tanda dengan objek bersifat diperkirakan. Untuk tanda tipe indeks pertama yaitu gambar Peci atau Kopiah yang dipakai di kepala $\mathrm{H}$. Subadri. Peci menginterpretasikan sebuah identitas keagamaan. Setiap agama memiliki jenis dan bentuk peci yang berbeda-beda, namun dalam hal ini H.Subadri memakai peci umat muslim yang berwarna hitam. Trend peci yang dipakai oleh para pejabat itu berasal dari Ir.Soekarno, maka dari itu peci yang dipakai oleh H. Subadri menggambarkan identitas agama sekaligus identitas kebangsaan nasional.

Tanda tipe indeks kedua adalah jenis dan warna pakaian yang dikenakan oleh $\mathrm{H}$. Subadri. Hubungan tanda dengan objek, merujuk pada gaya pakaian seorang yang memiliki status sosial tinggi. Dalam iklan cetak ini, H. Subadri dideskripsikan secara visual mengenakan setelan jas hitam, kemeja putih, dengan dasi putih bermotif batik. Jas hitam ini menggambarkan kesan formal, kaku, dan menunjukan status orang tersebut. Hal ini menginterpretasikan bahwa ia ingin menyampaikan kepada masyarakat bahwa ia memiliki sebuah status atau jabatan yang tinggi. Kemudian kemeja putih yang dikenakan H. Subadri terkesan simpel agar terlihat rapi dan profesional ketika di gabungkan dengan jas. Sedangkan dasi putih bercorak batik dengan warna hitam menggambarkan bahwa H.Subadri merupakan orang yang sangat mencintai seni dan budaya. Sehingga terkesan elegan dan menarik. 
Tanda indeks ketiga adalah tipografi yang digunakan dalam penggunaan teks iklan bakal calon walikota $\mathrm{H}$. Subadri . Hubungan tanda dengan objek adalah font yang digunakan. Terdapat tiga jenis font yang digunakan dalam iklan tersebut. Hubungan tanda dengan objek adalah font yang digunakan, yaitu huruf serif, san serif, dan script. Jenis huruf serif merupakan jenis huruf dasar dalam tipografi. Ciri hurufnya adalah dengan adanya goresan kecil atau ekor pada setiap akhir hurufnya. Jenis huruf serif membuat mata lebih nyaman saat melihat kumpulan huruf dalam jumlah banyak. Selain itu memberi kesan tegas dan klasik. Kemudian jenis huruf san serif merupakan kebalikan dari jenis font serif yang tidak memiliki ciri goresan kecil atau ekor pada akhir hurufnya. Jenis huruf ini terkesan lebih simple dan elegan namun kurang mencolok. Sehingga mencirikan makna tulisan yang hanya sebagai pelengkap saja.

Jenis font terakhir adalah script. Huruf jenis ini memiliki ciri seperti tulisan tangan manusia. Sehingga terkesan ramah, akrab, dan santai. Kaitan secara keseluruhan dengan tulisan yang ada di dalam iklan cetak bakal calon walikota H. Subadri adalah beliau mencoba untuk menyampaikan pesan secara jelas dengan menggunakan jenis font yang nyaman untuk dibaca. Hal tersebut mempertegas pesan utama yang ingin disampaikan $\mathrm{H}$. Subadri kepada masyarakat. Serta menampilkan sikap ramah dan akrab agar tidak terasa ada jarak atau kesenjangan dengan masyarakat.

\section{Interpretasi Makna berdasarkan Identifikasi Jenis Tanda Simbol}

Untuk klasifikasi tanda tipe simbol dalam iklan cetak bakal calon walikota Serang, maka terdapat tiga tanda tipe simbol. Pada tanda tipe simbol yang pertama, yaitu teks subheadline "Kang Badri”. Panggilan "Kang” menginter-pretasikan panggilan khas sunda yang berarti merujuk kepada seorang lelaki yang seumuran bahkan orang yang lebih tua. Seperti kata "kakak" dalam bahasa Indonesia agar terdengar lebih sopan dan akrab. Teks yang di cetak dengan tipe huruf script ini memperkuat maksud dan tujuan H. Subadri agar dapat terasa akrab dengan rakyat. Ditambah dengan warna merah yang memiliki arti kekuatan, keberanian, dan semangat semakin mempertegas akan keberaniannya untuk maju menjadi Walikota Serang 2018.

Selanjutnya yaitu kalimat "untuk Kota Serang 2018". Kalimat ini menginterpretasikan bahwa H. Subadri hadir dan siap atas segala tujuannya sebagai Walikota Serang 2018. Namun teks yang di cetak dengan jenis font san serif dan 
Volume 5 Nomor 1, April 2019

berukuran lebih kecil membuat kesan teks tersebut hanya pernyataan pelengkap saja dan tidak memiliki arti begitu penting.

Pada tanda tipe simbol kedua yaitu teks isi headline yang berupa identitas nama dan penyataan dari bakal calon walikota tersebut yaitu "H. Subadri Usuludin, SH Calon Walikota Serang 2018-2023”. Dalam teks headline ini interpretasinya adalah mengenai informasi siapakah calon tersebut dengan memberikan identitas nama lengkap beserta gelarnya untuk meyakinkan bahwa ia merupakan orang yang pantas karena berpendidikan. Kemudian penyataan beliau yang menuliskan bahwa ia merupakan calon walikota merupakan rasa optimis akan memenangkan suara rakyat.

Terakhir adalah tipe simbol ketiga yakni teks tagline atau slogan "Mewujudkan Kota Serang, Kota Santri, Berdaya \& Berbudaya" yang dipakai untuk menarik rakyat sekaligus merupakan tujuan-tujuan sebagai calon walikota Serang. Disini interpretasinya adalah bahwa H. Subadri ingin menjadikan wajah Kota Serang sebagai kota santri yang tetap melestarikan budaya.

Secara keseluruhan analisis wajah Kota Serang dalam iklan cetak bakal calon walikota Serang H. Subadri Usuluddin di representasikan sebagai berikut:

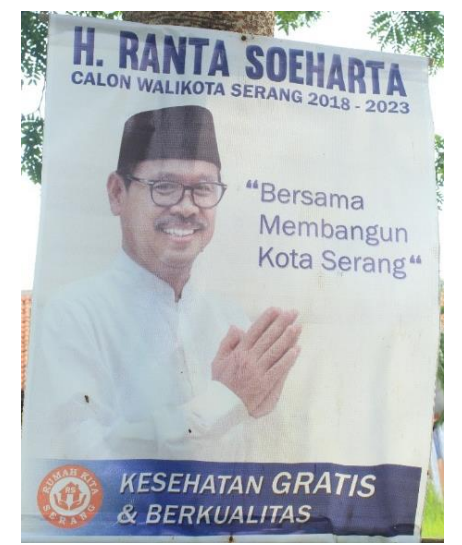

Gambar 2. H. Ranta Soeharta

\begin{tabular}{llll}
\hline Tanda & \multicolumn{1}{c}{ Penjelasan } & \multicolumn{1}{c}{ Identifikasi } \\
\hline Ikon & Tanda berhubungan dengan objek & $\bullet$ & H. Ranta Soeharta \\
& $\begin{array}{l}\text { karena adanya kesamaan, contohnya } \\
\text { peta atau foto. }\end{array}$ & $\bullet$ Latar belakang putih polos \\
& & $\bullet$ Logo Rumah Kita Serang \\
Indeks & $\begin{array}{l}\text { Adanya kedekatan eksistensi antara } \\
\text { tanda dengan objek atau adanya }\end{array}$ & - & Paris gradient biru tua \\
hubungan sebab akibat. & - Pakaian H. Ranta
\end{tabular}


Simbol Hubungan ini bersifat konvensional dalam artian ada persetujuan tertentu antara para pemakai tanda.
- Headline : H. Ranta Soeharta

- sub-Headline : Calon Walikota Serang 2018-2023

- Tagline 1 : Bersama Membangun Kota Serang

- Tagline 2 : Kesehatan Gratis \& Berkualitas

a. Wajah Kota Serang sebagai kota yang teratur, kota yang kental sekali akan budaya Islam dan kota yang masih menjunjung tinggi moral etika didalam masyarakat.

b. Kota Serang yang memiliki budaya Bhinneka Tunggal Ika yang tinggi dan tetap rukun berdampingan dan saling menghargai, menjunjung tinggi demokrasi.

\section{Interpretasi Makna berdasarkan Identifikasi Jenis Tanda dalam Iklan Cetak}

\section{H. Ranta Soeharta Bakal Calon Walikota Serang 2018}

Berdasarkan identifikasi tanda dalam iklan cetak bakal calon Walikota Serang 2018 yang dilakukan dengan mengadaptasi jenis-jenis tanda yang dikemukakan oleh Pierce, maka didapatkan tanda-tanda yang berupa ikon, indeks, dan simbol.

Setelah proses identifikasi, peneliti melakukan interpretasi terhadap makna yang terkandung dalam tanda-tanda tersebut.

\section{Interpretasi Makna berdasarkan Identifikasi Jenis Tanda Ikon}

Berdasarkan hasil identifikasi tanda yang dilakukan terhadap iklan bakal calon Walikota Serang H. Ranta, maka didapatkan empat tanda jenis ikon. Pada tanda jenis ikon pertama, terdapat visual foto H. Ranta Soeharta. Berdasarkan hubungan tanda dengan objek pada tipe ikon maka hubungan tanda dan objek dalam gambar ini sama yaitu gambar $\mathrm{H}$. Ranta Soeharta. Disini Interpretant-nya mengacu pada sosok H. Ranta Soeharta sebagai bakal calon yang merupakan Sekretaris daerah Pemerintahan Provinsi Banten kota Serang yang terlihat berpenampilan sangat sederhana, rapi, dan bersih namun islami.

Gaya berpakaiannya yang sangat sederhana tersebut membuat kesan merakyat karena tidak menonjolkan kesan seperti para pejabat. Pose fotonya yang menempelkan kedua telapak tangan didepan dada seperti orang yang memberi salam dalam budaya islam meng-gambarkan bahwa ia orang yang santun dan religius. Sosoknya yang sederhana, 
religius, dan santun merepresentasikan wajah kota Serang sebagai kota memiliki tingkat religius yang tinggi, masyarakat yang ramah dan juga santun.

Pada tanda ikon yang kedua yaitu warna latar belakang putih polos. Interpretantnya mengacu pada warna putih yang dipakai sebagai warna dasar pada iklan bakal calon walikota H. Ranta. Warna putih menggambarkan kemurnian, kesucian, bersih, dan sederhana. Memberikan kesan yang ringan dan higienis sesuai dengan tujuan yang ingin diterapkan oleh H. Ranta yaitu mengenai kesehatan.

Kemudian tanda ikon yang ketiga adalah logo Rumah Kita Serang. Interpretantnya mengacu pada logo tersebut. Hubungan antara tanda dengan objek yaitu Rumah Kita Serang merupakan lembaga koalisi yang mengusung H. Ranta Soeharta. Logo Rumah Kita menggambarkan hubungan, kedekatan dan dukungan untuk H. Ranta sebagai bakal calon walikota Serang.

Tanda ikon keempat yaitu bentuk segiempat dengan efek gradient biru tua. Bentuk segiempat dengan efek gradient biru tua menginterpretasikan ketenangan, stabilitas, dan kesetaraan. Warna biru tua yang dipakai menggambarkan profesionalisme dan pengalaman.

\section{Interpretasi Makna berdasarkan Identifikasi Jenis Tanda Indeks}

Pada tanda tipe indeks maka hubungan tanda dengan objek bersifat diperkirakan. Untuk tanda tipe indeks pertama yaitu gambar Peci atau Kopiah yang dipakai di kepala $\mathrm{H}$. Ranta berwarna hitam, sama seperti yang dipakai oleh H. Subadri. Peci menginterpretasikan sebuah identitas keagamaan. Hal ini menggambarkan bahwa adanya persamaan antara H. Subadri dengan H. Ranta. Mereka sama-sama seorang yang religius dan menjadikannya sebagai identitas kebangsaan nasional.

Tanda tipe indeks kedua adalah jenis dan warna pakaian yang dikenakan oleh $\mathrm{H}$. Ranta. Hubungan tanda dengan objek, merujuk pada gaya pakaian seorang yang sederhana dan religius. Dalam iklan cetak ini, H. Ranta dideskripsikan secara visual mengenakan setelan baju koko berwarna putih polos. Baju koko menggambarkan kesan religius, suci, dan sederhana. Hal ini menginterpretasikan H. Ranta ingin menyampaikan kepada masyarakat bahwa beliau adalah seorang yang merakyat meskipun beliau kini mejabat sebagai Sekretaris Daerah Pemerintahan Provinsi Banten. Hal ini memberikan kesan bahwa H. Ranta ingin setara dengan rakyat lainnya. Tidak ada perbedaan status sosial dan lain-lain. 
Tanda indeks ketiga adalah tipografi yang digunakan dalam penggunaan teks iklan bakal calon walikota H. Ranta . Hubungan tanda dengan objek adalah font yang digunakan. Terdapat satu jenis font yang digunakan dalam iklan tersebut. Hubungan tanda dengan objek adalah font yang digunakan, yaitu huruf san serif. Jenis huruf san serif tidak memiliki ciri goresan kecil atau ekor pada akhir hurufnya. Jenis huruf ini terkesan lebih simple dan elegan Namun kurang mencolok. Walaupun begitu penggunaan kontras tebal tipis dan ukuran huruf dapat membedakan pesan mana yang lebih diutamakan. Penggunaan jenis huruf san serif ini merepresentasikan kesederhanaan sama seperti tanda lainnya yang ditampilkan pada iklan cetak bakal calon walikota H. Ranta.

\section{Interpretasi Makna berdasarkan Identifikasi Jenis Tanda Simbol}

Untuk klasifikasi tanda tipe simbol dalam iklan cetak bakal calon walikota Serang, maka terdapat tiga tanda tipe simbol. Pada tanda tipe simbol yang pertama, yaitu teks Headline "H. Ranta Soeharta". Nama panjang yang dicantumkan oleh bakal calon tersebut menginterpretasikan identitas diri secara utuh agar dapat dikenal oleh masyarakat. Teks yang di cetak dengan tipe huruf san serif serta diikuti oleh penebalan (bold) dan ukuran yang lebih besar ini memperkuat maksud beliau agar dapat dikenal oleh masyarakat Serang. Selanjutnya tanda tipe simbol kedua adalah teks sub-headline yang berupa kalimat "Calon Walikota Serang 2018-2023”. Kalimat ini menginterpretasikan bahwa H. Ranta optimis akan memenangkan suara rakyat. Namun teks yang di cetak dengan jenis font san serif dan berukuran lebih kecil membuat kesan teks tersebut hanya pernyataan pelengkap dan penjelas saja.

Pada tanda tipe simbol ketiga yaitu teks isi tagline yang berisi "Bersama Membangun Kota Serang”. Teks tersebut tidak dicetak tebal (bold) namun cukup besar. Dalam teks tagline ini interpretasinya adalah mengenai informasi tujuan yang ingin beliau sampaikan kepada masyarakat. Kalimat teks tersebut menggambarkan sikap gotong royong dan kerja sama dalam melakukan pembangunan. H. Ranta terkesan ingin mengajak masyarakat untuk secara bersama-sama membangun kota Serang, karena pembangunan bisa berjalan dengan lancar apabila masyarakat ikut berpartisipasi dengan mematuhi dan menjaga apa yang telah pemerintah kerjakan untuk rakyat. Sedangkan tagline selanjutnya yang berisi "Kesehatan Gratis \& Berkualitas" memiliki perbedaan dengan tagline sebelumnya dikarenakan teks ditulis dengan menggunakan huruf kapital, sedangkan tagline 
sebelumnya tidak. Hal ini menginterpretasikan bahwa tagline kedua terlihat sangat diutamakan karena adanya penegasan dalam bentuk huruf kapital yang digunakan. Tagline kedua menggambarkan bahwa kesehatan gratis dan berkualitas menjadi fokus dalam tujuannya. Ditambah dengan perbedaan ukuran pada kata "Gratis" yang lebih besar dibanding satuan kata lain yang terkesan menarik perhatian masyarakat.

Maka, secara keseluruhan analisis wajah kota Serang dalam iklan cetak bakal calon walikota Serang H. Ranta Soeharta di representasikan sebagai berikut:

a. Wajah kota Serang sebagai kota memiliki tingkat religius yang tinggi, masyarakat yang ramah dan juga santun.

b. Kota Serang yang belum maksimal secara fasilitas kesehatan yang ramah untuk masyarakat yang tidak mampu sehingga perlu adanya peningkatan dan menjadi tujuan dari H. Ranta Soeharta.

c. Kota Serang dengan masyarakat yang mau bergotong royong dan bekerja sama dengan pemerintah dalam pembangunan kota Serang.

\section{Interpretasi Makna berdasarkan Identifikasi Jenis Tanda dalam Iklan Cetak} Nuraeni Bakal Calon Walikota Serang 2018

Berdasarkan identifikasi tanda dalam iklan cetak bakal calon Walikota Serang 2018 yang dilakukan dengan mengadaptasi jenis-jenis tanda yang dikemukakan oleh Pierce, maka didapatkan tanda-tanda yang berupa ikon, indeks, dan simbol. Setelah proses identifikasi, peneliti melakukan interpretasi terhadap makna yang terkandung dalam tandatanda tersebut.

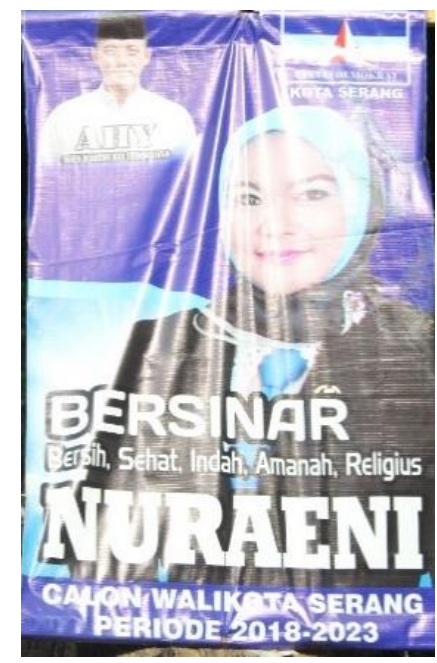

Gambar 3 Nuraeni 


\begin{tabular}{|c|c|c|}
\hline Tanda & Penjelasan & Identifikasi \\
\hline Ikon & $\begin{array}{l}\text { Tanda berhubungan dengan objek } \\
\text { karena adanya kesamaan, contohnya } \\
\text { peta atau foto. }\end{array}$ & $\begin{array}{ll}\text { - } & \text { Nuraeni } \\
\text { - } & \text { Agus Harimurti Yudhoyono } \\
& (\text { AHY }) \\
\text { - } & \text { Background biru tua dan biru } \\
\text { muda } \\
\text { - Logo Partai Demokrat }\end{array}$ \\
\hline Indeks & $\begin{array}{l}\text { Adanya kedekatan eksistensi antara } \\
\text { tanda dengan objek atau adanya } \\
\text { hubungan sebab akibat. }\end{array}$ & $\begin{array}{l}\text { - Pakaian Nuraeni } \\
\text { - Peci } \\
\text { - Pakaian AHY } \\
\text { - } \text { Tipografi }\end{array}$ \\
\hline Simbol & $\begin{array}{l}\text { Hubungan ini bersifat konvensional } \\
\text { dalam artian ada persetujuan tertentu } \\
\text { antara para pemakai tanda. }\end{array}$ & $\begin{array}{ll}\text { - } & \text { Headline : Nuraeni } \\
\text { - } & \text { Sub-headline : Calon Walikota } \\
& \text { Serang Periode 2018-2023 } \\
\text { - } & \text { Tagline : BERSINAR (Bersih, } \\
& \text { Sehat, Indah, Amanah, Religius). }\end{array}$ \\
\hline
\end{tabular}

\section{Interpretasi Makna berdasarkan Identifikasi Jenis Tanda Ikon}

Berdasarkan hasil identifikasi tanda yang dilakukan terhadap iklan bakal calon Walikota Serang Nuraeni, maka didapatkan empat tanda jenis ikon. Pada tanda jenis ikon pertama, terdapat visual foto Nuraeni. Berdasarkan hubungan tanda dengan objek pada tipe ikon maka hubungan tanda dan objek dalam gambar ini sama yaitu gambar Nuraeni. Disini Interpretant-nya mengacu pada sosok Nuraeni sebagai enterpreneur wanita di kota Serang yang terlihat berpenampilan formal namun tetap menarik dari segi style dan makeup yang digunakan.

Gaya berpakaiannya yang formal namun tetap stylish tersebut membuat kesan menarik, tidak hanya cantik namun berpendidikan. Sosoknya menggambarkan wanita enterpreneur sosialita yang memiliki banyak pengetahuan dan wawasan sehingga terlihat cerdas. Hal tersebut menunjukan bahwa ia memiliki kemampuan dibidang perekonomian dan usaha. Namun dilihat dari latar belakang Nuraeni sebagai pengusaha wanita tidak sesuai dengan jargon atau slogan yang di cantumkan yang ingin mewujudkan kota Serang yang bersih, sehat, dan indah. Sebenarnya dengan menggunakan latar belakang tersebut ia bisa mewujudkan peningkatan perekonomian dan lapangan kerja.

Pada tanda ikon kedua, terdapat pula visual foto Agus Harimurti Yudhoyono atau biasa dikenal dengan sebutan AHY. Berdasarkan hubungan tanda dengan objek pada tipe ikon maka hubungan tanda dan objek dalam gambar ini yaitu sosok AHY yang merupakan 
sekjen dari partai yang mengusung Nuraeni yaitu Demokrat. Disini Interpretant-nya mengacu pada sosok AHY sebagai sekjen partai Demokrat yang terlihat berpenampilan sederhana. Keberadaan visual sosok tersebut menginterpretasikan sebuah dukungan penuh terhadap calon yang diusungnya yaitu Nuraeni. Selain itu AHY menggambarkan sebuah kedudukan dan eksistensi yang dikenal oleh publik.

Kemudian tanda ikon yang ketiga adalah logo bendera partai Demokrat. Interpretantnya mengacu pada logo tersebut. Hubungan antara tanda dengan objek yaitu partai Demokrat merupakan partai yang mengusung Nuraeni. Logo partai Demokrat menggambarkan hubungan, kedekatan dan dukungan untuk Nuraeni sebagai bakal calon walikota Serang. Selain itu logo tersebut menginterpretasikan identitas Nuraeni sebagai anggota partai Demokrat.

Tanda ikon yang keempat yaitu warna latar belakang biru tua dan biru muda. Interpretantnya mengacu pada penggunaan warna yang sesuai dengan warna bendera partai Demokrat. Warna biru tua menginterpretasikan sikap profesionalitas dan pengalaman. Memberikan kesan yang serius dalam bekerja. Sedangkan warna biru muda menginterpretasikan kepercayaan dan ketenangan.

\section{Interpretasi Makna berdasarkan Identifikasi Jenis Tanda Indeks}

Pada tanda tipe indeks maka hubungan tanda dengan objek bersifat diperkirakan. Untuk tanda tipe indeks pertama adalah jenis dan warna pakaian yang dikenakan oleh Nuraeni. Hubungan tanda dengan objek, merujuk pada gaya pakaian seorang yang cerdas dan memiliki suatu passion dalam dirinya.

Dalam iklan cetak ini, Nuraeni dideskripsikan secara visual mengenakan setelan jas hitam, kemeja putih, dan dasi biru muda kemudian dengan jilbab biru muda dan hitam dihiasi dengan bros di sisi kirinya. Jas hitam yang dipakai Nuraeni sama seperti yang dipakai oleh H. Subadri yaitu menggambarkan kesan formal, kaku, dan menunjukan status orang tersebut. Hal ini menginterpretasikan bahwa ia ingin menyampaikan kepada masyarakat bahwa ia memiliki sebuah status yang cukup berpengaruh. Kemudian kemeja putih yang dikenakan Nuraeni terkesan simpel agar terlihat rapi dan profesional ketika di gabungkan dengan jas. Ditambah dengan dasi biru muda senada dengan salah satu warna yang dipakai dalam logo bendera partai Demokrat yang menggambarkan sebuah kepercayaan dan identitas. 
Selanjutnya yaitu jilbab yang dipakai oleh Nuraeni. Jilbab tersebut bermodel biasa dan sederhana yang hanya di pakai sesuai bentuk muka dan diikatkan kebelakang lehernya dengan riasan bros yang sederhana pula. Kerudung atau jilbab menginterpretasikan sebuah identitas agama yakni agama Islam. Hal ini tersebut menggambarkan ketaatan seorang muslimah dalam menjalankan kewajiban. Warna biru muda dan hitam pada kerudung yang dipakai oleh Nuraeni juga memiliki kesesuaian dengan style secara keseluruhan dan tak lepas dari warna identitas partai yaitu biru.

Tanda tipe indeks yang kedua yaitu jenis dan warna pakaian yang dikenakan oleh Agus Harimurti Yudhoyono (AHY). Hubungan tanda dengan objek, merujuk pada gaya pakaian seorang yang sederhana dan religius. Dalam iklan cetak ini tokoh tambahan yaitu Agus Harimurti dideskripsikan secara visual mengenakan setelan baju koko berwarna putih polos mirip seperti pakaian yang dikenakan oleh H. Ranta. Baju koko menggambarkan kesan religius, suci, dan sederhana. Hal ini menginterpretasikan AHY yang ingin menyampaikan kepada masyarakat bahwa beliau adalah seorang yang merakyat meskipun beliau merupakan sekjen partai Demokrat dan anak dari mantan presiden Indonesia yaitu Susilo Bambang Yudhoyono. Selanjutnya adalah Peci atau Kopiah yang dipakai di kepala AHY berwarna hitam, sama seperti yang dipakai oleh H. Subadri dan H. Ranta yang menginterpretasikan sebuah identitas keagamaan. Mereka sama-sama seorang yang religius dan menjadikannya sebagai identitas kebangsaan nasional.

Tanda indeks ketiga adalah tipografi yang digunakan dalam penggunaan teks iklan bakal calon walikota Nuraeni. Hubungan tanda dengan objek adalah font yang digunakan. Terdapat dua jenis font yang digunakan dalam iklan tersebut. Hubungan tanda dengan objek adalah font yang digunakan, yaitu huruf serif dan san serif. Sama seperti yang sudah dipaparkan diatas jenis huruf serif yang juga dipakai dalam iklan cetak H. Subadri merupakan jenis huruf dasar dalam tipografi. Ciri hurufnya adalah dengan adanya goresan kecil atau ekor pada setiap akhir hurufnya. Jenis huruf serif membuat mata lebih nyaman saat melihat kumpulan huruf dalam jumlah banyak. Selain itu memberi kesan tegas dan klasik. Kemudian jenis huruf san serif yang terkesan lebih simple dan elegan. Jenis huruf san serif tidak memiliki ciri goresan kecil atau ekor pada akhir hurufnya. Jenis huruf ini terkesan lebih simple dan elegan. Penggunaan kontras tebal tipis dan ukuran huruf dapat membedakan pesan mana yang lebih diutamakan. Penggunaan jenis huruf san serif ini merepresentasikan kesederhanaan. 


\section{Interpretasi Makna berdasarkan Identifikasi Jenis Tanda Simbol}

Untuk klasifikasi tanda tipe simbol dalam iklan cetak bakal calon walikota Serang, maka terdapat tiga tanda tipe simbol. Pada tanda tipe simbol yang pertama, yaitu teks Headline yang berupa identitas nama dari bakal calon walikota tersebut yaitu "Nuraeni". Dalam teks headline ini interpretasinya adalah mengenai informasi siapakah calon tersebut dengan memberikan identitas nama depan atau nama panggilan yang membuatnya mudah untuk diucapkan dan diingat. Terlebih tulisan tersebut dicetak dengan ukuran yang lebih besar dari pada yang lain, agar dapat dengan mudah dilihat dari kejauhan. Apalagi dengan penggunaan jenis font serif yang menggambarkan penegasan terhadap tulisan tersebut.

Tanda tipe simbol yang kedua adalah teks Sub-headline yang berupa tulisan "Calon Walikota Serang Periode 2018-2023”. Kalimat ini menginterpretasikan bahwa Nuraeni yang bersikap optimis akan memenangkan suara rakyat. Namun teks yang di cetak dengan jenis font san serif dan berukuran lebih kecil membuat kesan teks tersebut hanya pernyataan pelengkap dan penjelas saja.

Terakhir adalah tipe simbol ketiga yakni teks tagline atau slogan "BERSINAR" yang merupakan sebuah singkatan. Dilengkapi dibawahnya dengan kepanjangan dari kata "Bersinar" tersebut yakni "Bersih, Sehat, Indah, Amanah, Religius" yang dipakai untuk menarik rakyat sekaligus merupakan tujuan-tujuan sebagai calon walikota Serang. Disini interpretasinya adalah bahwa Nuraeni ingin menjadikan wajah kota Serang sebagai kota yang bersih lingkungannya, sehat rakyatnya, indah, amanah, dan religius. Penggunaan singkatan tersebut sangat menarik perhatian dan bertujuan agar mudah diingat. Diikuti dengan kalimat kepanjangannya dari akronim "Bersinar" sebagai kalimat penjelas.

Maka, secara keseluruhan analisis wajah kota Serang dalam iklan cetak bakal calon walikota Serang Nuraeni di representasikan sebagai berikut:

a. Wajah kota Serang sebagai kota yang bersih lingkungannya, sehat rakyatnya, indah dan religius.

b. Nuraeni ingin menjadi seorang pemimpin yang amanah dimata masyarakat. Dengan sosok yang cerdas dan berwawasan luas. 
Volume 5 Nomor 1, April 2019

\section{Interpretasi Makna berdasarkan Identifikasi Jenis Tanda dalam Iklan Cetak}

\section{Vera Nurlaela Jaman Bakal Calon Walikota Serang 2018}

Berdasarkan identifikasi tanda dalam iklan cetak bakal calon Walikota Serang 2018 yang dilakukan dengan mengadaptasi jenis-jenis tanda yang dikemukakan oleh Pierce, maka didapatkan tanda-tanda yang berupa ikon, indeks, dan simbol. Setelah proses identifikasi, peneliti melakukan interpretasi terhadap makna yang terkandung dalam tandatanda tersebut.

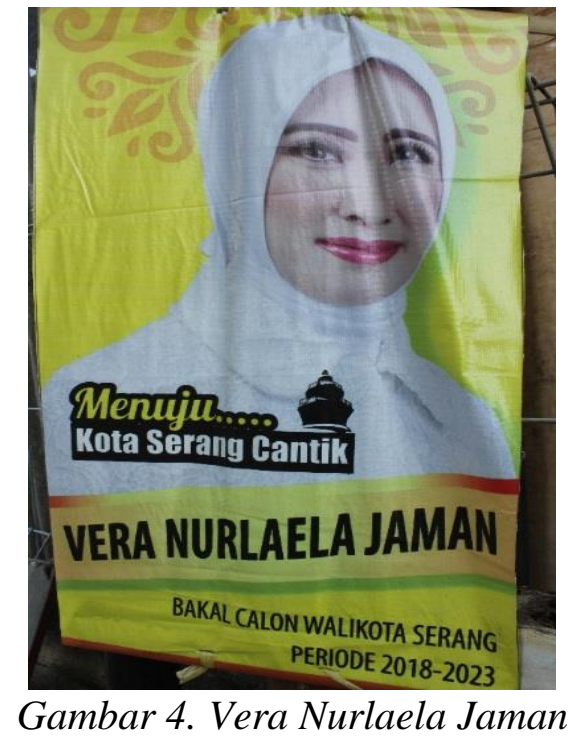

\begin{tabular}{|c|c|c|}
\hline Tanda & Penjelasan & Identifikasi \\
\hline Ikon & $\begin{array}{l}\text { Tanda berhubungan dengan } \\
\text { objek karena adanya kesamaan, } \\
\text { contohnya peta atau foto. }\end{array}$ & $\begin{array}{l}\text { - Vera Nurlaela Jaman } \\
\text { - Latar Belakang } \\
\text { - Siluet Menara Banten } \\
\text { - Ornamen }\end{array}$ \\
\hline Indeks & $\begin{array}{l}\text { Adanya kedekatan eksistensi } \\
\text { antara tanda dengan objek atau } \\
\text { adanya hubungan sebab akibat. }\end{array}$ & $\begin{array}{l}\text { - Pakaian Vera Nurlaela Jaman } \\
\text { - Tipografi }\end{array}$ \\
\hline Simbol & $\begin{array}{l}\text { Hubungan ini bersifat } \\
\text { konvensional dalam artian ada } \\
\text { persetujuan tertentu antara para } \\
\text { pemakai tanda. }\end{array}$ & $\begin{array}{ll}\text { - } & \text { Tagline : Menuju Kota Serang } \\
\text { Cantik } \\
\text { - Headline : Vera Nurlaela Jaman } \\
\text { - Sub-headline : BAKAL CALON } \\
\text { WALIKOTA SERANG PERIODE } \\
\text { 2018-2023 }\end{array}$ \\
\hline
\end{tabular}




\section{Interpretasi Makna berdasarkan Identifikasi Jenis Tanda Ikon}

Berdasarkan hasil identifikasi tanda yang digunakan terhadap iklan cetak Vera Nurlaela Jaman, maka didapatkan tiga tanda jenis ikon. Pada tanda jenis ikon pertama, terdapat visual gambar Vera Nurlaela Jaman. Disini interpretant-nya mengacu kepada sosok Vera Nurlaela Jaman sebagai Bakal Calon Walikota Serang 2018-2023. Dilihat dari besarnya gambar bisa dimaknakan bahwa Vera adalah orang besar dan terpandang. Vera merupakan istri dari walikota Serang yaitu Tb. Haerul Jaman. Dilihat dari penampilan-nya dia menunjukan kecantikan dengan make-up serta lipstik yang dipakainya. Dibalut dengan kerudung dan pakaian tertutup berwarna putih ini mempresentasikan makna seorang pemimpin muslimah yang modern. Jika tanda ikon pertama yaitu visual Vera Nurlaela Jaman, maka interpretasi yang terbentuk adalah bahwa Bakal Calon Vera tengah berupaya untuk menyampaikan makna kecantikan sebagai gambaran Kota Serang dalam kepemimpinanya, sosok cantik yang di tampilkan menjadi tujuannya untuk kepemimpinannya yang akan datang.

Pada tanda ikon kedua yaitu gambar latar belakang, menampilkan sebuah ornamen, dengan dominan warna kuning yang bermakna secara umum, warna terang seperti halnya kuning, memberikan kesan ceria, bahagia, energik, dan rasa optimis.

Dibalik warna background berwarna kuning, yaitu karena Vera berasal dari partai Golongan Karya (Golkar) yang sama-sama memiliki latar belakang berwarna kuning, terdapat arti lain dari sebuah warna kuning yaitu orang orang yang bijaksana, kreatif serta piawai dalam menciptakan ide dan inovasi. Maka interpretant-nya adalah vera nurlaela jaman ingin membawa kota serang menjadi kota yang ceria, bijaksana dalam hal apapun, kreatif serta inovasi di segala bidang.

Tanda ikon ketiga yaitu siluet menara Banten, pada gambar ini interpretant-nya Vera ingin mengelola kembali Banten lama, yang oleh pemimpin sebelumnya sempat tidak diperhatikan keberadaannya sehingga Banten lama kumuh tak terawat, Vera ingin mengembalikan Banten Lama menjadi pusat destinasi keagamaan di Kota Serang. Karena Banten lama sebuah kiblat sejarah dan peninggalan kesultanan Sultan Ageng Tirtayasa di Provinsi Banten.

Tanda ikon keempat yaitu ornamen, pada ornamen tersebut terlihat, simple, luwes dan tidak kaku dalam ukirannya, ornamen tersebut berwarna coklat yang bisa di artikan elegan dalam sebuah ornamen tersebut. Pada gambar ini bisa di interpretasikan bahwa Vera 
ingin membawa kota serang kearah yang lebih sederhana dan luwes ke dalam setiap pembawa di dalam pemerintahannya.

\section{Interpretasi Makna berdasarkan Identifikasi Jenis Tanda Indeks}

Pada tanda tipe indeks maka hubungan tanda dengan objek bersifat diperkirakan. Untuk tanda tipe indeks pertama adalah model pakaian yang dikenakan Vera Nurlaela Jaman. Hubungan tanda dengan objek merujuk pada pakaian seorang muslim yang modern dalam berpenampilan. Mengenakan baju brukat panjang berukir berwarna putih dan menggunakan jilbab berwarna putih. Perpaduan yang cukup netral dan aman untuk dikombinasikan.

Dalam konsep warna hubungannya dengan kepribadian. Vera juga mengenakan riasan tipis di wajahnya, dan lipstik berwarna merah menginterpretasikan seorang Vera Nurlaela Jaman ingin mejadikan kota Serang sebagai kota yang cantik, mulai dari tatanan kotanya serta kepribadian.

Pakaian yang dikenakan cukup elegan dan agamis, dengan ini Vera juga ingin menampilkan sebuah keeleganan dalam memerintah kota Serang di eranya. Warna merah membalut bibir Vera ini memiliki arti semangat dan berani.

Tanda kedua dalam kategori tanda tipe indeks adalah tipografi (jenis font atau tulisan) yang digunakan dalam penulisan teks iklan. Setiap font memiliki "personality" atau image tertentu. Hubungan tanda dengan objek adalah font yang digunakan, yaitu script huruf tulisan ini menyerupai tulisan tangan yaitu huruf letter, maka interpretant-nya terhadap font yang digunakan dalam iklan cetak ini adalah bersifat ramah dan mudah akrab.

Serta font san serif yang digunakan,tulisan ini biasa di gunakan dalam sebuah teks undangan ataupun hal-hal akademis lainnya, tulisan ini cukup netral bagi para pembacanya. Jenis huruf san serif yang terkesan lebih simple dan elegan. Jenis huruf san serif tidak memiliki ciri goresan kecil atau ekor pada akhir hurufnya. Jenis huruf ini terkesan lebih simple dan elegan. Penggunaan kontras tebal tipis dan ukuran huruf dapat membedakan pesan mana yang lebih diutamakan. Penggunaan jenis huruf san serif ini merepresentasikan kesederhanaan. Pada kedua Font tersebut menunjukkan bahwa interpretasi jika dikaitkan dengan wajah kota Serang, maka yang terdapat pada font yaitu keramahan serta keakraban dan netralitas kepada khalayak yaitu masyarakat kota Serang itu sendiri. 


\section{Interpretasi Makna berdasarkan Identifikasi Jenis Tanda Simbol}

Untuk klasifikasi tanda tipe simbol dalam iklan cetak Bakal Calon Walikota Serang 2018 - 2023 versi Vera Nurlaela Jaman, maka terdapat tiga tanda tipe simbol. Pada tanda tipe simbol pertama, yaitu teks Tagline "Menuju Kota Serang Cantik" jika dilihat dari kalimatnya, Vera ingin mengajak masyarakat untuk mempercantik kota Serang, terinspirasi dari kota Tangerang yang masih satu provinsi, agar bisa menata dan mempercantik kota Serang, selaku Ibukota Provinsi Banten. Interpretasi terhadap tanda ini, bahwa cantik dan indah kotanya sudah pasti cerminan dari masyarakatnya. Mencoba untuk menjadi salah satu kota inspiratif di Indonesia.

Tanda simbol kedua yaitu teks headline "Vera Nurlaela Jaman" yaitu mewakili sebuah desain sebagai identitas pada iklan cetak tersebut. Teks headline tersebut memiliki kontras huruf yang besar, interpretasi-nya terhadap tanda ini adalah sebuah penegasan dari calon tersebut, untuk di ingat oleh masyarakat.

Pada simbol ketiga yaitu teks sub-headline "Bakal Calon Walikota Serang 2018. Periode 2018-2023", dalam tanda teks sub-headline ini, interpretasinya adalah adanya keraguan untuk maju ke tingkat atas yaitu pencalonan, berbeda dengan yang sudah optimis dan siap akan maju ke Calon Walikota Serang 2018-2023. Sub-headline ini memberikan sebuah informasi tentang kesiapan seorang Calon Walikota Serang 2018-2023.

Kesimpulan pada pamflet milik Vera Nurlaela Jaman cukup merepresentasikan wajah Kota Serang, dilihat dari empat ikon, dua indeks dan 3 simbol. Dari kesimpulan di atas dapat di representasikan bahwa Vera Nurlaela Jaman, adalah sosok yang yang cantik, agamis dan elegan yang tergambarkan di dalam kepemimpinannya, selain orangnya yang luwes dan mudah bersosialisasi di balik itu Vera memiliki tujuan yang ingin mengedepankan kecantikan kota serta tata kelola pemerintahannya, dengan mengembalikan fungsi Banten lama dan membuat masyarakat menjadi nyaman dengan visualisasi yang dia buat di dalam pamflet tersebut.

Maka, secara keseluruhan analisis wajah kota Serang dalam iklan cetak bakal calon walikota Serang Vera Nuelaela Jaman di representasikan sebagai berikut:

1. Wajah kota Serang yang cantik dalam tata kotanya serta pemerintahannya, menjadikan kota yang religius, santun dan ramah kepada seluruh masyarakatnya.

2. Membangun kota Serang yang indah, memperhatikan dan merawat situs Banten Lama. 


\section{Interpretasi Makna berdasarkan Identifikasi Jenis Tanda dalam Iklan Cetak}

\section{H Lalu Atharussalam Bakal Calon Walikota Serang 2018}

Berdasarkan identifikasi tanda dalam iklan cetak bakal calon Walikota Serang 2018 yang dilakukan dengan mengadaptasi jenis-jenis tanda yang dikemukakan oleh Pierce, maka didapatkan tanda-tanda yang berupa ikon, indeks, dan simbol. Setelah proses identifikasi, peneliti melakukan interpretasi terhadap makna yang terkandung dalam tandatanda tersebut.

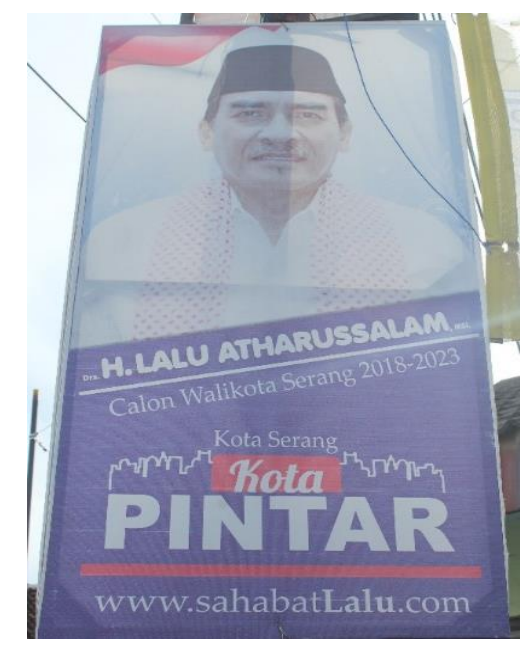

Gambar 5. H. Lalu Atharussalam

\begin{tabular}{|c|c|c|}
\hline Tanda & Penjelasan & Identifikasi \\
\hline Ikon & $\begin{array}{l}\text { Tanda berhubungan dengan } \\
\text { objek karena adanya kesamaan, } \\
\text { contohnya peta atau foto. }\end{array}$ & $\begin{array}{l}\text { - H. Lalu Atharussalam } \\
\text { - } \quad \text { Background Putih, Merah dan } \\
\text { Biru tua } \\
\text { - } \quad \text { Grafik Gedung Perkotaan }\end{array}$ \\
\hline Indeks & $\begin{array}{l}\text { Adanya kedekatan eksistensi } \\
\text { antara tanda dengan objek atau } \\
\text { adanya hubungan sebab akibat. }\end{array}$ & $\begin{array}{l}\text { - Pakaian H. Lalu Atharussalam } \\
\text { - Tipografi }\end{array}$ \\
\hline Simbol & $\begin{array}{l}\text { Hubungan ini bersifat } \\
\text { konvensional dalam artian ada } \\
\text { persetujuan tertentu antara para } \\
\text { pemakai tanda. }\end{array}$ & $\begin{array}{ll}\text { - } & \text { Headline : H. Lalu } \\
& \text { Atharussalam } \\
\text { - } & \text { Tagline : Kota Serang Kota } \\
& \text { PINTAR } \\
\text { - } & \text { Sub-headline : Bakal Calon } \\
& \text { Walikota Serang 2018-2023 } \\
\text { - } & \text { Mondatories : } \\
& \text { www.sahabatLalu.com }\end{array}$ \\
\hline
\end{tabular}


Volume 5 Nomor 1, April 2019

\section{Interpretasi Makna berdasarkan Identifikasi Jenis Tanda Ikon}

Berdasarkan hasil identifikasi tanda yang digunakan terhadap iklan cetak H. Lalu Atharussalam sosok yang besar dan terpandang seperti seorang ulama besar di kota Serang. Dilihat dari posisi pengambilan gambar besar dan posisi medium shot ini merepresentasikan makna seorang pemimpin yang besar, agamis dan santun di era sekarang.

Jika tanda ikon pertama yaitu visual H. Lalu Atharussalam, maka interpretasi yang terbentuk adalah bahwa calon $\mathrm{H}$. Lalu Atharussalam ingin menyampaikan makna yang santun, agamis serta humanis dalam kepemimpinannya. Mantan sekda Banten ini sangat ingin mengubah kota Serang menjadi kota yang pintar "Smart City" seperti di beberapa kota besar lainnya yang sudah mulai menerapkannya.

Dengan semangat dan tekatnya yang bulat, calon Walikota Serang ini maju dengan mencalonkan diri sebagai calon di jalur independent dan dibantu oleh para relawannya di Kota Serang, pengalamannya di dunia pemerintahan tidak menyusutkan asanya untuk maju ke pencalonan Walikota Serang 2018-2023. Jika dilihat interpretasi-nya H. Lalu ingin

membuat kota Serang memiliki semangat yang tidak pernah padam, suci serta bersih didalam pemerintahannya.

Pada tanda ikon kedua yaitu gambar latar belakang, menampilkan sebuah warna yang dominan berwarna putih dan ada sedikit warna merah. Jika dilihat pada latar belakang warna tersebut interpretant-nya warna putih yang bisa dimaknai suci dan bersih dan merah yang bisa di maknai dengan keberanian dan semangat. Dan warna biru tua yang bermakna profesional dan pengalaman. Dalam desain pun cukup simpel tidak banyak bermain warna.

Tanda ikon ketiga grafik gedung perkotaan, pada gambar ikon ketiga interpretantnya H. Lalu ingin membuat kota Serang menjadi kota pintar "Smart City", setelah kotakota besar mencoba menerapkan di kota Serang jikalau dirinya terpilih nanti. Memang tidak ada salahnya mencoba menggunakan sebuah perencanaan smart city ini. Namun perlu dilihat juga sejauh mana perencanaan itu matang, karena dalam pamflet smart city yang diinginkan tidak cukup jelas, mau seperti apa. Apakah hanya ingin mengubah menjadi kota yang penuh dengan gedung-gedung pencakar langit seperti di ibukota Jakarta? Atau memajukan mencerdaskan dengan meng-upgrade sistem yang ada di kotanya agar tidak lagi ketinggalan. 
Interpretasi pada ikon ketiga ingin menjadikan kota yang lebih maju seperti kotakota lain yang telah lebih dahulu. Dilihat dari letak kota Serang yang berada di tengahtengah perkotaan jelas memiliki makna bahwa H Lalu ingin membuat kota Serang lebih baik dari kota-kota lain di era yang serba digital ini.

\section{Interpretasi Makna berdasarkan Identifikasi Jenis Tanda Indeks}

Pada tanda tipe indeks maka hubungan tanda dengan objek bersifat diperkirakan. Untuk tanda tipe indeks pertama adalah model pakaian yang dikenakan H. Lalu Atharussalam. Hubungan tanda dengan objek, merujuk pada pakaian seorang muslim yang santun dan orang yang di tuakan dalam keagamaan. Mengenakan Baju koko panjang berwarna putih dan menggunakan selendang berwarna putih dan merah.

Dalam konsep warna hubungannya dengan kepribadian H. Lalu adalah seorang yang religius serta tokoh yang kuat di kota Serang, mimik wajah yang tersenyum menunjukkan bahwa dia adalah seorang yang ramah. Maka interpretasi-nya adalah H. Lalu orang yang yang suci serta bersih, sosok yang terpandang di kota Serang, yang ingin membawa kotanya maju tanpa harus melanggar norma-norma agama islam didalamnya.

Tanda indeks kedua adalah tipografi yang digunakan dalam penggunaan teks iklan calon walikota H. Lalu Atharussalam. Hubungan tanda dengan objek adalah font yang digunakan. Terdapat Hubungan tanda dengan objek adalah font yang digunakan. Terdapat satu jenis font yang digunakan dalam iklan tersebut. Hubungan tanda dengan objek adalah font yang digunakan, yaitu huruf san serif. Jenis huruf san serif tidak memiliki ciri goresan kecil atau ekor pada akhir hurufnya. Jenis huruf ini terkesan lebih simple dan elegan. Walaupun begitu penggunaan kontras tebal tipis dan ukuran huruf dapat membedakan pesan mana yang lebih diutamakan. Penggunaan jenis huruf san serif ini merepresentasikan kesederhanaan sama seperti tanda lainnya yang ditampilkan pada iklan cetak bakal calon walikota lainnya.

\section{Interpretasi Makna berdasarkan Identifikasi Jenis Tanda Simbol}

Untuk klasifikasi tanda tipe simbol dalam iklan cetak calon walikota Serang, maka terdapat empat tanda tipe simbol. Pada tanda tipe simbol yang pertama, yaitu teks Headline "H. Lalu Atharussalam". Nama panjang yang dicantumkan oleh bakal calon tersebut menginterpretasikan identitas diri secara utuh agar dapat dikenal oleh masyarakat. Terdapat sebuah gelar di bagian headline namun tidak di tonjolkan seperti nama panjangnya, ini 
menginterpretasikan bahwa beliau hanya ingin dikenal namanya saja tidak perlu dengan gelar yang telah dia peroleh.

Tanda tipe simbol kedua adalah teks Tagline yang berupa kalimat "Kota Serang Kota PINTAR". Kalimat ini menginterpretasikan bahwa H. Lalu ingin membawa kota Serang menjadi kota yang pintar, pada kalimat "PINTAR" dicetak tebal (bold) dan sangat besar diantara kalimat lainnya, bahwa $\mathrm{H}$. Lalu pada taglinenya ingin menegaskan sebagai kota yang pintar. Pintar kotanya pintar juga masyarakat kotanya.

Tanda tipe simbol ketiga adalah teks subheadline yang berupa kalimat "Calon Walikota Serang 2018-2023”. Kalimat ini menginterpretasikan bahwa H. lalu optimis maju ke kursi Walikota Serang. Kalimatnya dibuat miring mengikuti dengan kalimat headline yang menyesuaikan dengan desain background-nya yang miring.

Pada simbol keempat yakni teks mandatories (penyelenggara atau produsen) yang berisi mengenai website "www.sahabatLalu.com". Di sini interpretasinya dalam iklan cetak mendatories merupakan sebuah website untuk mendukung $\mathrm{H}$ Lalu dalam pencalonannya di Walikota Serang tahun 2018-2023. Teks mendatories di sini juga bisa merepresentasikan mengenai kemodernan seperti pada tagline-nya kota Pintar (Smart City). Jadi para pendukung $\mathrm{H}$ Lalu tidak harus datang untuk ikut mendukung cukup mengakses website-nya melalui internet jika ingin menjadi relawan dan pendukungnya.

Maka, secara keseluruhan analisis wajah kota Serang dalam iklan cetak bakal calon walikota Serang H. Lalu Atharussalam di representasikan sebagai berikut:

a. Wajah kota Serang yang religius dalam pemerintahannya, menjadikan kota yang maju dalam teknologi dan system pemerintahannya.

b. Membangun kota Serang menjadi kota yang pintar, pintar kotanya pintar juga warganya tanpa harus meninggalkan atau melanggar norma agama di kota Serang. Walaupun Smart City yang di inginkan tidak cukup jelas hanya ada grafik gedung perkotaan saja di dalam iklan cetak.

\section{Representasi Wajah Kota Serang dalam Iklan Cetak Para Bakal Calon Walikota Serang 2018}

Banyak cara untuk menyampaikan ajakan memilih para bakal calon Walikota Serang 2018, salah satunya yaitu menggunakan iklan cetak sebagai alat peraga kampanye, yang bertujuan mengajak kepada masyarakat untuk memilih dan menunjukkan siapa sosok 
yang akan dipilih pada Pilkada Walikota Serang 2018 nantinya. Alat peraga kampanye tentunya sangat membantu para bakal calon Walikota Serang sebagai petunjuk dan pengenalan dirinya dalam bentuk desain grafis yang kemudian di cetak lalu di sebarkan ke pemukiman warga untuk dilihat. Biasanya dalam membuat pamflet para bakal calon (balon) memiliki ciri khas tersendiri pada alat peraganya tersebut. Bisa dari pakaian lalu, corak warna yang dibuat dengan menarik mungkin untuk memikat warga untuk memilih dirinya. Ada yang berupa slogan yang dibuat dengan kreatif mungkin untuk menjanjikan para warga kedepannya ketika sang balon tersebut dipilih untuk memimpin di wilayah tersebut.

Para balon berupaya mengajak masyarakat dengan cara membuat sebuah pamflet, dan di dalam pamflet di pamflet para bakal calon Walikota Serang 2018 memiliki makna yang berbeda-beda di setiap gambarnya. Dengan ini diperlukan sebuah teori Representasi untuk mendapatkan makna dalam iklan cetak milik para bakal calon Walikota Serang 2018. Hal tersebut dapat terungkap dengan menggunakan teori semiotika Charles Sanders Pierce yaitu mengenai Ikon, Indeks dan Simbol. Dari tiga tanda tersebut akan terungkap sebuah makna dibalik bahasa yang tertuang pada iklan cetak para balon Walikota Serang 2018. Dengan ketiga tanda tersebut akan memudahkan peneliti mendapatkan meneliti iklan cetak tersebut. Menggunakan ketiga tanda tersebut peneliti menemukan gambaran Wajah Kota Serang 2018 di iklan cetak Bakal Calon.

Penggambaran seorang pemimpin di dalam sebuah iklan cetak poster/pamflet, yang kemudian di bagi ke dalam tiga tanda, setelah dilakukan pembagian maka dilakukan sebuah pembentukan makna yang tertanam di dalam iklan cetak sang balon. Seperti pada calon Vera Nurlaela Jaman yang memiliki tanda pada wajah alias parasnya yang cantik. sebagai penyelaras dengan tagline yang di usungnya sebagai Kota Serang Kota Cantik itu adalah salah satu makna didalam sebuah pesan gambar yang ada di iklan cetak milik Vera Nurlaela Jaman. Lalu pada bagian background Vera terdapat warna kuning yang dominan itu bisa saja memaknai sebagai suatu partai pengusung dan makna kreatif, inovatif dan menjadi sosok yang bijaksana.

Gambaran yang terlihat di dalam iklan cetak para bakal calon Walikota Serang 2018 dilihat dari tiga tanda milik Charles Sanders Pierce yaitu Ikon, Indeks dan Simbolnya melihat ikon pada balon Ahmad Subadri terdapat kerumunan orang yang sedang memegang sebuah tongkat bendera merah putih dan memakai pakaian adat yang berbeda-beda menggambarkan sekumpulan orang yang Bhineka Tunggal Ika di kota Serang. Kemudian 
tanda pada Indeks di pasangan bakal calon Walikota Serang yang mengenakan pakaian dan penggunaan typografi di dalam poster/pamflet yang memiliki makna terhadap kepribadian sosok sang calon. Hal tersebut terdapat hubungan sebab dan akibat. Pada tanda simbol memiliki gambaran berupa kalimat seperti slogan yang di gunakan besar kecilnya nama pasangan calon dan huruf yang digunakannya.

\section{KESIMPULAN}

Berdasarkan hasil analisis semiotika terhadap wajah Kota Serang 2018 iklan cetak bakal calon Walikota Serang 2018, maka dapat ditarik kesimpulan bahwa :

Setiap balon memiliki ciri khas terhadap desain yang dibuatnya untuk mengajak masyarakat memilih dirinya menjadi Walikota Serang 2018. Dengan daya tarik yang dibuat kreatif, masyarakat pun bisa melihat hal yang ingin disampaikan melalui desain poster para balon. Tidak hanya dengan tagline saja, tetapi pakaian yang dikenakan dan tidak jauh dari norma yang telah disepakati oleh masyarakat kota Serang yaitu ciri religius dan sikap ramah tamahnya.

Setelah melakukan pemaknaan menggunakan tiga tanda Charles Sanders Pierce diketahui dengan adanya hubungan antara ikon, indeks dan simbol di dalam sebuah tanda berupa gambaran kepribadian, prinsip, serta tujuan yang ingin dicapai bakal calon nantinya terpilih yang diuraikan memberikan makna tersendiri. Makna semiotika yang merepresentasikan wajah kota Serang yaitu sebagai kota yang religius, damai, dan bermoral.

\section{DAFTAR PUSTAKA}

Giles, Judy dan Tim Middleton. (1999). Studying Culture: A Practical Introduction. Blackwell Publisher: Oxford.

Girsang, Lasmery RM dan Indah, Hapsari. (2015) Makna Optimisme Dalam Iklan Politik "Wujudkan Mimpi Bersama Jokowi-Jk” (Analisis Semiotika Saussure Pada Scene yang Menunjukkan Tagline Jokowi-Jk Adalah Kita), Jurnal Seniotika Volume 9. No. $1,145-146$.

Kriyantono, Rahmat. (2006). Teknik Praktis Riset Komunikasi. Jakarta:Kencana Prenada Media Group.

Rakhmat, Jalaluddin. (2007). Metode Penelitian Komunikasi. Bandung: PT Remaja Rosdakarya. 
Sobur, Alex. 2009. Semiotika Komunikasi. Bandung: PT Remaja Rosdakarya.

Surahman, Sigit. (2014). Konstruksi Identitas Postmodern dalam Iklan La Light Versi Don't Quit", Jurnal Lontar Volume 2. No.3, 25.

Surahman, Sigit. (2014). Representasi Perempuan Metropolitan dalam Film 7 Hati 7 Cinta 7 Wanita, Jurnal Lontar Volume 3. No.2, 44.

Ulfa, Ruzqiyah. (2016). Analisis Semiotika Peirce Pakaian Jenis Gamis Sebagai Representasi Budaya Arab, Jurnal Semiotika Volume 10. No. 2, 404.

Vihma Susann dan Seppo Vakeka, 2009. Semotika Visual dan Semantika Produk, Yogyakarta: Jalasutra. 